\title{
Pengaruh Budaya Organisasi Terhadap Motivasi Kerja Anggota Club K Universitas Negeri Jakarta
}

\author{
${ }^{1}$ Dinday Ayu Firanti, ${ }^{2}$ Indah Sulistiani, ${ }^{3}$ Marisa Puspita Sary \\ ${ }^{123}$ Universitas Negeri Jakarta \\ email : dindaayufiranti_1410619059@mhs.unj.ac.id
}

\begin{abstract}
Abstrak
Budaya organisasi berperan penting dalam sebuah lingkungkan organisasi dimana hal itu akan berpengaruh terhadap banyak hal. Penelitian dibuat untuk mengetahui ada atau tidaknya pengaruh budaya organisasi terhadap motivasi kerja dalam organisasi Club K Universitas Negeri Jakarta. Metode deskriptif kuantitatif diguanakan dalam penelitian menggunakan teknik analisis regresi linear sederhana. Peneliti juga menggunakan program spss sebagai alat ukur untuk melakukan uji ke validan data dan reliabilitas data. Teknik pegumpulan data melalui kuesioner dengan menggunakan google formulir untuk melaksanakan penelitian ini. Hasil penelitian ini membawa hasil yaitunilai signifikansi kurang dari nilai probabilitas signifikan dan memiliki makna bahwa budaya dalam organisasi berpengaruh terhadap motivasi kerja anggota organisasi Club $\mathrm{K}$ Universitas Negeri Jakarta. Budaya organisasi yang baik akan mempengaruhi suasana dalam organisasi sehingga menimbulkan motivasi kerja anggota organisasi.
\end{abstract}

Kata Kunci :Budaya, Budaya Organisasi, Motivasi Kerja

\begin{abstract}
Organizational culture plays an important role in an organizational environment where it will affect many things. The study was made to determine whether or not the influence of organizational culture on work motivation in the Club K organization, Jakarta State University. Quantitative descriptive methods are used in research using simple linear regression analysis techniques. Researchers also use the SPSs program as a measuring tool to test the validity of data and data reliability. The technique of collecting data through a questionnaire using google forms to carry out this research. The results of this study bring the results, namely, the significance value is less than the significant probability value and means that the culture in the organization affects the work motivation of the members of the Club K organization, Jakarta State University. A good organizational culture will affect the atmosphere in the organization, giving rise to the work motivation of organizational members.
\end{abstract}

Keyword: Culture, Organizational Culture, Work Motivation

\section{PENDAHULUAN}

Sumber Daya Manusia adalah hal penting di organisasi, tanpa ada nya Sumber Daya Manusia yang berkualitas maka suatu organisasi tidak berjalan dengan baik. Dalam suatu organisasi sangat di butuhkan penggerak mulai dari pimpinan hingga bawahan. Penggerak ini dapat berupa motivasi dorongan yang dapat menimbulkan giat bekerja dengan penuh semangat terlebih kerja yang di lakukan ini ikhlas tanpa ada nya rasa keterpaksaan di dalam diri anggota karyawan.

Ciri khas atau faktor yang dapat membedakan organisasi satu dengan organisasi yang lain yaitu budaya. Budaya adalah hal yang sangat erat di masyarakat, budaya menjadikan suatu ciri khas dari suatu masyarakat dalam cara bertindak pengambilan keputusan ataupun interaksi denan orang lain. Kemajuan zaman ini tentunya budaya tidak hanya hadir pada lingkup masyarakat saja tetapi budaya juga pasti akan tercipta dalam suatu organisasi. Tidak sedikit manfaat dari budaya dalam organisasi ini tentunya memberikan kontribusi yang baik bagi terciptanya suatu tujuan perusahaan atau organisasi secara menyeluruh (Yusuf, 2017) 
Dalam keseharian masyarakat, kegiatan yang terjadi selalu memiliki hubungan dengan ikatan budaya yang sudah ada sebelumnya. Budaya tercipta dalam masyarakat baik itu dalam keluarga maupun organisasi. Budaya pada dasarnya adalah salah satu hal yang dapat membedakan individu satu dengan individu lainnya ketika memiliki kontak interaksi dan mencari solusi atau jalan keluar dalam suatu masalah yang menghadapinya. Budaya juga dapat mengikat masing masing anggota kelompok dimana orang memandang anggota dalam kelompok atau organisasi tersebut berperilaku dan bertindak dengan cara yang sama. Budaya yang terbentuk dalam organisasi memiliki manfaat dan efektif terutama bagi para anggota.

Budaya organisasi merupakan suatu hal yang menjadi ciri khas pada suatu perusahaan atau organisasi, tentunya hal ini akan memberikan pengaruh pada cara seseorang berperilaku dan tentunya akan menjadi asas padaf program yang dimiliki pada organisasi untuk pengembangan organisasi serta kebijakan - kebijakan yang di pilih juga. Tentunya hal ini terhubung dengan pengaruh budaya organisasi terhadap diri seseorang dan budaya mempengaruhi organisasi.

Disampaikan bahwa budaya organisasi ialah sistem bersama yang dipatuhi kemudian di ikuti olh pada anggota organisasi dimana hal ini tentunya menunjukkan identituas yang dapat membentuk ciri khas atau membedakan organisasi satu dengan organisasi lain. (Judge \& Robbins 2015). Di definisikan oleh (Theresia et al., 2018) bahwa budaya organisasi merupakan suatu keyakinan secara bersama kemudian mempersatukan anggota pada suatu organisasi dan penyatuan anggota organisasi dibawah norma perilaku serta aturan yang sudah di tetapkan di dalam organisasi.

Definisi diatas menunjukkan hasil bahwa budaya oranisasi merupakan sikap di organisasi.Budaya organisasi pada dasarnya adalah nilai dasar, kebiasan, harapan dan keyakinan yang dipunyai seluruh anggota organisasi yang dipakai sebagai pedoman dalam menjalankan tuas untuk mencapai kesuksesan organisasi.

Yukl (Sunyoto 2013) menyampaikan terdapat fungsi utama dalam budaya organisasi ialah untuk membantu memahami lingkungan kerja dan juga menentukan cara merespon, sehingga hal ini akan menurukan rasa cemas, kebingungan dan ketidak pastian. Sunyoto juga menyampaikan terdapat dua fungsi utama dalam budaya organisasi yaitu budaya integrasi internal dimana fungsi ini anggota organisasi bisa menyatu sehingga anggota akan memahami bagaimana cara untuk berinteraksi dengan anggota lain. Fungs integasi internal memberikan identitas kolektif dan juga memberikan arahan tentang anggota dapat bekerjasama dengan efektif sebagai bentuk dari cara adaptasi eksternal, budaya organisasi ini juga akan memberikan arah bagaimana organisasi dapat mencapai tujuan dan dapat berhubungan dengan pihak lain. Budaya organisasi mengacu pada kawanan yang memiliki keyakinan bersama, tata hubungan, sikap dan juga asumsi yang spesifik atau implisit diterima dan kemudian diguanakan oleh seluruh anggota organisasi dalam menjalankan serta menghadapi lingkungan eksternal organisasi guna capai tujuan organisai.

Menurut Edison, Anwar, dan Komariyah dalam (Bodroastuti, 2018)dimensi dan indikator dalam budaya organisasi adalah keagresifan, kesadaran diri, orientasi tim, kepribadian, dan performa. Kesadara diri berarti bahwa anggota organisasi sadar bahwa mereka bekerja dalam organisasi untuk mendapatkan kepuasan terhadap kinerja mereka. Keagresifan berarti bahwa anggota organisasi berani untuk membuat suatu keputusan dan tujuan yang menantang. Kepribadian berarti bahwa anggota organisasi memiliki sikap terbuka sesama anggota dan ramah. Performa berarti anggota organisasi memiliki kreativitas dalam bekerja sebagai anggota organisasi. orientasi tim berarti bahwa dalam organisasi tersebut setiap anggota bisa bekerjasama berkomunikasi dengan baik.

Menurut (Tania, 2013)memotivasi para anggota organisasi dapat dilakukan dengan memberi feedback tentang bagaimana pekerjaan mereka. Memberikan motovasi kepada anggota juga dianggap hal yang penting karena keberhasilan dalam sebuah organisasi itu benar benar ditentukan atau dilihat dari hasil kerja yang juga dilakukan oleh seluruh anggota organisasi. Sebagai seorang pemimpin, sudah 
sepatutnya membagi tugas yangdikerjakan oleh anggota organisasi yang sebelumnya sudah ditetapkan. Dalam hal ini pemmpin dalam organisasi juga harus menciptakan suasana yang nyaman, memberi perhatian dan penghargaaan hingga menjalin komunikasi yang efektif dengan seluruh angggota organisasi.

Tidak hanya pemimpin, budaya organisasi juga besar kaitannya dengan suasana dalam organisasi dan dapat membuat lingkungan kerja organisasi menjadi lebih nyaman sehingga hal itu dapat menimbullkan hubungan yang baik pula dengan anggota organisasi yang lain. Budaya organisasi yang mengarah kepada hal positif dapat membuat para anggota organisasi terhindar dari keadaan stress kerja atau dengan kata lain berada dibawah tekanan. Hal itu dapat diatasi ketika terdapat budaya organisasi yang positif dalam organisasi tersebut. Namun hal ini bertolak belakang apabila sebuah organisasi memiliki budaya yang negatif dan anggota organisasi bekerja dalam tekanan karena suasana yang buruk, itu menyebabkan motivasi anggota organisasi menurun dalam bekerja (Az zuhri \& Permanasari, 2019)

Motivasi adalah situasi dimana terdapat sebuah dorongan yang terjadi pada anggota organisasi untuk dapat bekerja sesuai dengan visi misi sebuah organisasi yang dijalankan sehingga anggota organisasi dapat mengambil sebuah tindakan. Ketika para anggota organisasi memiliki pikiran yang baik dan positif dengan suasana organisasi yang nyaman, itulah yang dapat menjadi salah satu penyebab dan alasan kuat anggota organisasi dalam motivasinya terhadap bekerja di sebuah organisasi sehingga kerja nya akan maksimal.

Motivasi kerja bagi seorang anggota ataupun karyawan tentunya akan memberikan dampak yang besar bagi jalan nya suatu perusahaan atau organisasi dikarenakan secara langsung tentunya akan mempengaruhi kinerja anggota atau karyawan. Keahlian seseorang ialah suatu ukuran yang paling pertama dalam meningkatkan kinerja yang di tunjukkan dari hasil kerja. Mayoritas orang yang bekerja atau ikut serta di dalam organisasi tentunya mereka ingin melaksanakan pekerajaan nya dengan sepenuh hati, memberikan yang terbaik dan mencapai hasil yang maksimal.Motivasi kerja merupakan usaha yang dapat menimbulka, memelihara sikap individu sesuai di lingkungan kerja dan mengarahkan.Motivasi kerja ini melatar belakangi sikap seseorang di dalam organisasi. Motivasi kerja di definisikan yaitu segala sesuatu yang dapat menghadirkan gairah, keinginan dan energy dalam diri yang dapat memberikan pengaruh serta memberikan arah dan juga memelihara perilaku untuk mencapai tujuan yang diharapkan (Sitorus, 2020)

Motivasi kerja akan naik atau turun dalam menjalankan pekerjaannya, naik turun nya motivasi ini tentu akan mempengaruhi kinerja seorang anggota organisasi atau pun karyawan perusahaan. Motivasi kerja tentunya perlu di tegakkan dengan kepribadian pada diri masing - masing individu dikarenakan dorongan atau gerakan pada motivasi kerja yang didasarkan pada prinsip yang salah maka akan memberikan akibat kerugian secara pribadi maupun organisasi (Taruh, 2020).

Dalam organisasi, ketika budaya yang terbentuk adalah budaya yang baik maka akan sejalan dengan tingkat motivasi kerja para anggotanya. Jika organisasi tersebut juga memiliki budaya yang kuat dalam menciptakan suasana dan membuat puas anggota organisasi, maka hal itu juga dapat meningkatkan motivasi kerja anggota organisasi (Weerasinghe, 2017)

Menurut Mcclellan dalam(Ridha, 2020), ia meneliti mengenai tiga kebutuhan dan ini menjadi dimensi dan indikator dalam penelitian ini. Tiga kebutuhan tersebut adalah kebutuhan akan kekuasaan (need for power), kebutuhan akan pencapaian (need for achievment), kebutuhan akan berafiliasi (need for affiliation)

Penelitian terdahulu dilakukan oleh Ruhban Masykur dan rekannya ditahun 2019 mengenai pengaruh dari budaya organisasi terhadap motivasi kerja pada guru di sekolah dasar Ar Raudah yang berlokasi di bandar lampung dengan kuantitatif sebagai metodenya dan dari hasil penelitian tersebut menyebutkan bahwa ada pengaruh yang mengarah ke positif dan signifikan pada motivasi kerja guru di 
sekolah dasar Ar Raudah(Masykur, Et. Al., 2019)

Sutoro tahun 2020 melakukan penelitian mengenai budaya organisasi dan motivasi kerja dengan sampel penelitiannya adalah pegawai BPSDM di Provinsi Jambi. Dalam penelitiannya menyebutkan budaya organisasi yang baik mendorong motivasi karyawan dalam bekerja. Motivasi yang relatif tinggi berhubungan dengan prestasi serta dedikasi karyawan dalam bekerja sehingga itu akan meningkatkan kinerja karyawan dalam bekerja (Sutoro, 2020).

Kemudian pada tahun 2017, Sarah Sucia Ramadhani dan rekannya melakukan penelitian mengenai budaya organisasi dan motivasi kerja serta dampaknya pada kinerja karyawan di Direktorat Jenderal Pajak. Kuantitatif juga dipakai dalam penelitian dengan metode survey. Hasil dari penelitiannya menunjukkan bahwa kuat atau lemahnya budaya organisasi dalam direktorat jenderal pajak berpengaruh positif pada motivasi kerja karyawannya. (Ramadhani et al., 2017)

Club K merupakan sebuah organisasi kemahasiswaan di Fakultas Ilmu Sosial, Universitas Negeri Jakarta. Club K berdiri ketika pendirinya melihat keadaan mahasiswa yang ada di Fakultas Ilmu Sosial masih minim wadah dan informasi terutama untuk mengembangkan English skills. Akhirnya pada tahun 2016 terbentuklah Organisasi Club K oleh salah satu mahasiswa Fakultas Ilmu Sosial dengan rekan tim nya sebagai sebuah solusi dari urgensi wadah dan pengembangan informasi dalam bidang Bahasa Inggris.

Organisasi Club $\mathrm{K}$ juga memilikivisi yaitu menjadi fasilitator dan wadah untuk mahasiswa Fakultas Ilmu Sosial, Universitas Negeri Jakarta untuk mengembangkan potensi, kreatifitas, dan inovasi dalam bidang Bahasa Inggris. Kemudian terdapat 3 misi dari organisasi Club $\mathrm{K}$ yaitu membantu anggota organisasi meningkatkan kemampuan mereka dalam berbahasa Inggris, menyediakan tutor yang capable untuk mengembangkan anggota dan organisasi, serta membangun kerjasama atau relasi dengan eksternal juga memberikan informasi seputar lomba atau kegiatan yang dapat diikuti oleh seluruh anggota Club K.

Anggota organisasi Club K yang banyak dan berasal dari berbagai macam program studi dalam Fakultas Ilmu Sosial, Universitas Negeri Jakarta membuat anggota organisasi Club K harus beradaptasi dengan budaya yang dibentuk dalam organisasi. Kemajemukan latar belakang anggota organisasi Club $\mathrm{K}$ yang akhirnya membuat peneliti tertarik untuk meneliti budaya organisasi dan motivasi kerja para anggotanya. Sehingga rumusan masalah yang di dapat dalam penelitian ini adalah"apakah ada pengaruh antara budaya organisasi terhadap motivasi kerja anggota organisasi Club K?"

Sedangkan penelitian ini bertujuan untuk mencari tahu ada atau tidaknya pengaruh budaya organisasi terhadap motivasi kerja anggota organisasi Club K. Peneliti berharap penelitian ini dapat memperkuat teori budaya organisasi dan motivasi untuk menyampaikan faktor dalam motivasi kerja anggota organisasi dan terutama dapat di manfaatkan untuk penelitian selanjutnya terutama pada bidang Ilmu Komunikasi dan bidang lain yang sesuai serta dapat menjadi masukan yang dapat dipertimbangkan oleh organisasi Club K terutama dalam meningkatkan motivasi kerja dan memperkuat budaya organisasi pada organisasi Club K.

\section{METODE}

Penelitian ini ialah penelitian kuantitatif deskriptif menggunakan kuesioner untuk dibagikan kepada anggota Club K Fakultas Ilmu Sosial, Universitas Negeri Jakarta.Menurut Kriyantono dalam (Ardian, 2013) survey merupakan salah satu metode dimana menggunakan kuesioner sebagai salah satu bagian dari data yang akan dikumpulkan memiliki tujuanmendapatkan informasi mengenai responden yang mewakili populasi. Metode survey digunakan untuk mengumpulkan data mengenai budaya organisas serta kaitannya dengan motivasi kerja pada organisasi Club K Universitas Negeri Jakarta 
Dalam mengumpulkan data data yang diperlukan oleh peneliti sekaligus menganalisis datanya dilakukan pendekatan kuantitatif dimana data dianalisis secara statistik sehingga terdapat gambaran sosial megenai objek yang diteliti(Sugiyono, 2019) Pendekatan kuantitatif digunakan secara khusus untuk dapat menganalisa budaya organisasi terhadap motivasi kerja, Sedangkan, pendekatan verifikatif sendiri digunakan dengan maksud untuk dapat menerapkan analisis (data) yang lebih rinci dan mendalam. Budaya organisasi merupakan variabel bebas $(\mathrm{X})$ sedangkan motivasi kerja adalah variabel terkat (Y) yang diteliti.

Teknik penarikan sampel yang digunakan adalah probability sampling melalui teknik random sampling anggota dalam populasi memiliki kesempatan yang sama menjadi sampel penelitian sehingga teknik sampel ini tidak memperhatikan stratanya.(Sugiyono, 2019) Populasi penelitian ini adalah anggota organisasi Club K Universitas Negeri Jakarta yang saat ini berjumlah 180 orang. Peneliti menggunakan rumus slovin dengan kesalahan ditentukan oleh peneliti sebesar 5\% dalam menentukan sampel yang datanya akan dikumpulkan. dari rumus tersebut maka didapatkan bahwa sampel pada penelitian ini berjumlah 124 responden.

Variabel bebas dalam penelitian ini adala budaya organisasi sedangkan variabel terikat nya adalah motivasi kerja. Dapat disajikan dengan kerangka teoritis sebagai berikut

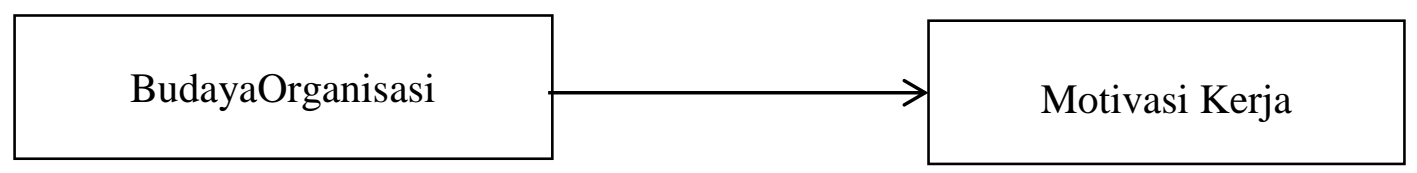

\section{HASIL DAN PEMBAHASAN}

Suharso mengatakan dalam Tjoeng dan Indriyani (2014) bahwa validitas merupakan sebuah pengukuran yang hasilnya dapat dilihat dengan jelas bagaimana tingkat valid atau ketepatan sebuah variabel atau konsep yang diangkat oleh peneliti, dimana sebuah variabel dikatakan sebagai pernyataan yang tepat apabila tingkat validitasnya memperoleh angka yang tinggi. Penelitian ini menggunakan rumus Keiser Meyer Olkin (KMO) untuk menguji valid atau tidaknya sebuah variabel.

\section{Tabel 1 Uji Validitas Variabel (X) Budaya Organisasi \\ KMO and Bartlett's Test \\ Kaiser-Meyer-Olkin Measure of Sampling Adequacy. , 782}

Approx. Chi-Square

280,274

Bartlett's Test of Sphericity

Df

15

Sig.

Tabel 1 ialah data yang diperoleh dari uji validitas dikaji dengan program SPSS 21. Tabel menunjukkan nilai KMO yang diperoleh dari data yang dikumpulkan adalah 0,782. Dikatakan bahwa 
sebuah data dapat disebut sebagai data yang valid jika nilainya $>0,5$. Dalam uji validitas dilakukan pada variabel budaya organisasi nilai KMO nya >0,5 yang berarti data tersebut termasuk data yang valid.

\section{Tabel 2 Uji Validitas Variabel (Y) Motivasi Kerja}

KMO and Bartlett's Test

Kaiser-Meyer-Olkin Measure of Sampling Adequacy. ,702

Bartlett's Test of Sphericity

Approx. Chi-Square
178,267
Df
,15
Sig.
, 000

Tabel 2 menunjukkan KMOvariabel terikat yang diteliti yaitu motivasi kerja. Data menunjukkan angka 0,702 sebagai nilai KMO. Sama seperti pernyataan yang disebutkan, maka data untuk variabel motivasi kerja merupakan data yang valid karena nilainya lebih besar dari 0,5.

\section{Tabel 3 Uji Reliabilitas Variabel (X) Budaya Organisasi}

\begin{tabular}{l}
\multicolumn{2}{c}{ Reliability Statistics } \\
\hline Cronbach's N of \\
Items \\
Alpha \\
\hline, 826 \\
6 \\
\hline
\end{tabular}

Suharso juga mengatakan mengenai reliabilitas dalam (Indriyani, 2014)merupakan data atau pernyataan yang hasil olahannya menjamin isi datanya atau dengan kata lain dapat dilihat apakah datanya konsisten dan stabil atau tidak. Dalam mengukur ke stabilan datanya, Pengukuran cronbach alpha dilakukan dengan program SPSS. Dikatakan sebuah data dapat menjadi data yang reliabel apabila nilai crobach alpha nya $>0,6$. Pada tabel 3 nilai cronbach alpha dari pengukurannya menunjukkan angka 0,826 yang berarti bahwa data pada variabel budaya organisasi adalah data yang reliabel dan cukup stabil.

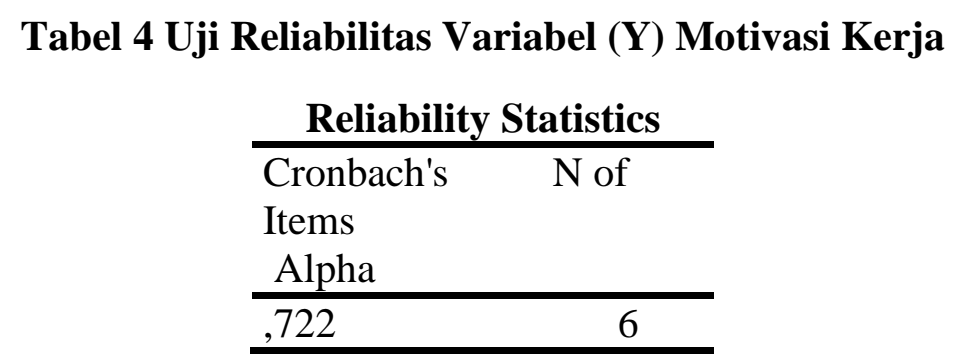

Pada tabel 4 merupakan hasil pengukuran reliabilitas untuk variabel motivasi kerja. Nilai pada pengukuran cronbach alpha menunjukkan angka 0,722 yang berarti data yang dikumpulkan peneliti untuk variabel motivasi kerja merupakan data yang reliabel karena lebiih besar dari 0,6. 
Tabel 5 Analisis Deskriptif Variabel Budaya Organisasi

\begin{tabular}{|c|c|c|c|c|c|c|c|}
\hline No & Pernyataan & STS & $\begin{array}{c}\mathrm{TS} \\
2\end{array}$ & $\mathrm{~S}$ & $\begin{array}{c}\mathrm{SS} \\
4\end{array}$ & $\mathrm{~N}$ & Mean \\
\hline 1 & Melakukan usaha yang terbaik untuk organisasi & 1 & 9 & 40 & 74 & 124 & 3,51 \\
\hline 2 & $\begin{array}{l}\text { Menetapkan rencana sendiri dan menyelesaikan } \\
\text { pekerjaan dengan benar }\end{array}$ & - & 6 & 43 & 75 & 124 & 3,56 \\
\hline 3 & $\begin{array}{l}\text { Menghargai dan menghormati sesama anggota } \\
\text { organisasi }\end{array}$ & - & 8 & 45 & 71 & 124 & 3,51 \\
\hline 4 & Mengutamakan kualitas dalam pekerjaan & - & 16 & 55 & 53 & 124 & 3,30 \\
\hline 5 & Mampu bekerjasama dengan rekan dalam organisasi & - & 15 & 49 & 60 & 124 & 3,36 \\
\hline 6 & Berusaha membantu antar anggota & - & 9 & 59 & 56 & 124 & 3,38 \\
\hline
\end{tabular}

Dalam tabel 5 dapat dilihat bahwa terdapat 10 orang dalam organisasi yang tidak melakukan usaha yang terbaik untuk organisasi sementara 111 anggota berusaha yang terbaik. Dalam hal keagresifan 6 orang menyatakan tidak setuju untuk menetapkan rencana sendiri sementara 118 lainnya memiliki rencana sendiri dan menyelesaikan pekerjaannya dengan benar. 8 anggota merasa tidak menghargai dan menghormati anggota lainnya sementara 116 anggota berusaha untuk menghormati dan menghargai satu sama lain. 16 orang menyatakan tidak setuju dengan kualitas sebagai hal yang utama dalam pekerjaan. Sementara itu dalam hal orientasi terhadap tim, 15 anggota belum mampu bekerjasama antar anggota karena masih menyesuaikan diri namun hal ini tertutup dengan banyaknya anggota lain yang melakukan perilaku positif dalam organisasi.

Tabel 6 Analisis Deskriptif Variabel Motivasi Kerja

\begin{tabular}{llcccccc}
\hline \multirow{2}{*}{ No Pernyataan } & STS & TS & S & SS & \multirow{2}{*}{ N } & \multirow{2}{*}{ Mean } \\
\cline { 3 - 5 } & & 1 & 2 & 3 & 4 & & \\
\hline \multirow{2}{*}{1} & $\begin{array}{l}\text { Selalu meningkatkan produktivitas untuk mencapai } \\
\text { prestasi }\end{array}$ & - & 31 & 59 & 34 & \multirow{2}{*}{124} & 3,02 \\
\hline 2 & Mengerjakan tugas sesuai standar yang ditetapkan & - & 19 & 54 & 51 & 124 & 3,26 \\
\hline 3 & Membantu dan mendorong anggota organisasi & - & 16 & 51 & 57 & 124 & 3,33 \\
\hline 4 & Merasa memiliki tanggung jawab pada hasil kerja & - & 7 & 50 & 67 & 124 & 3,48 \\
\hline 5 & Berani mengeluarkan pendapat dalam organisasi & - & 7 & 54 & 63 & 124 & 3.45 \\
\hline 6 & $\begin{array}{l}\text { Berkomunikasi dan menjalin hubungan dengan baik } \\
\text { sesama anggota }\end{array}$ & 1 & 11 & 47 & 65 & 124 & 3,42 \\
\hline
\end{tabular}

Pada tabel 6 dapat dilihat bahwa 31 anggota tidak setuju mengenai mereka yang meningkatkan produktivitas kerja hanya untuk meraih prestasi sementara 93 orang setuju bahwa produktivitas ditingkatkan untuk mencapai prestasi. 19 orang menyatakan tidak setuju bahwa mereka mengerjakan tugas mereka sesuai dengan standar yang ditetapkan sementara 105 anggota mengerjakan sesuai dengan ketentuan yang ada. 16 orang mengaku tidak setuju untuk membantu dan mendorong anggota organisasi untuk menyelesaikan tugas organisasi sementara 108 orang saling membantu. 7 orang menyatakan tidak setuju bahwa mereka memiliki tanggung jawab terhadap hasil yang didapatkan oleh anggota organisasi sementara 117 orang setuju bahwa mereka memiliki tanggung jawab terhadap hasil kerja organisasi. 7 orang masih belum berani untuk mengeluarkan pendapatnya dalam organisasi smentara 117 sudah mampu untuk mengeluarkan pendapatnya ditengah organisasi. 12 orang merasa bahwa mereka belum 
mampu berkomunikasi dan menjalin kerjasama yang baik sesama anggota organisasi sementara 112 orang sudah menjalin hubungan organisasi dengan baik.

Tabel 7 Uji Normaliitas Residual

One-Sample Kolmogorov-Smirnov Test

\begin{tabular}{llr}
\hline & & $\begin{array}{r}\text { Unstandardiz } \\
\text { ed Residual }\end{array}$ \\
\hline $\mathrm{N}$ & Mean & 124 \\
Normal Parameters & a,b &, 0000000 \\
& Std. & 2,50346238 \\
Most Extreme & Deviation & \\
Differences & Absolute &, 095 \\
Kolmogorov-Smirnov Z & Positive &, 095 \\
Asymp. Sig. (2-tailed) & Negative &,- 073 \\
\multicolumn{2}{l}{ Asyme } & 1,055 \\
\hline
\end{tabular}

a. Test distribution is Normal.

b. Calculated from data.

Hasil olahan yang tertera pada tabel 7 nilai signifikansi yang diperoleh melalui uji normalitas residual adalah 0,215 >0,05 artinya data dari dua variabel yang diteliti dalam penelitian ini berdistribusi dengan normal.

Tabel 8 Uji Linearitas

ANOVA Table

\begin{tabular}{|c|c|c|c|c|c|c|c|}
\hline & & & $\begin{array}{c}\text { Sum of } \\
\text { Squares }\end{array}$ & $\mathrm{df}$ & $\begin{array}{l}\text { Mean } \\
\text { Square }\end{array}$ & $\mathrm{F}$ & Sig. \\
\hline \multirow{5}{*}{$\begin{array}{l}\text { Motivasi Kerja * } \\
\text { Budaya Organisasi }\end{array}$} & & (Combined) & 163,610 & 12 & 13,634 & 2,245 & ,014 \\
\hline & Between & Linearity & 66,990 & 1 & 66,990 & 11,028 & ,001 \\
\hline & Groups & Deviation from & 96,620 & 11 & 8,784 & 1,446 &, 163 \\
\hline & \multicolumn{2}{|c|}{ Within Groups } & 674,261 & 111 & 6,074 & & \\
\hline & \multicolumn{2}{|l|}{ Total } & 837,871 & 123 & & & \\
\hline
\end{tabular}

Tabel 8 menunjukkan hasil uji linearitas. Nilai signifikansi yang terdapat pada tabel tersebut adalah 0,163>0,05 sehingga terdapat hubungan linear yang bersignifikan antara kedua variabel. Kemudian dapat dilihat nilai $\mathrm{F}$ hitung pada tabel tersebut sebesar 1,446 dalam penelitian ini $\mathrm{F}$ tabel nya adalah sebesar 1,880 . Nilai $\mathrm{F}<\mathrm{F}$ besar dapat diartikan bahwa dari dua variabel yang diteliti yaitu budaya organisasi dan motivasi kerja memiliki hubungan linear yang bersignifikan. 


\section{Tabel 9. Uji Hipotesis}

\section{Coefficients $^{\mathrm{a}}$}

\begin{tabular}{|c|c|c|c|c|c|c|}
\hline \multirow{2}{*}{\multicolumn{2}{|c|}{ Model }} & \multicolumn{2}{|c|}{$\begin{array}{c}\text { Unstandardized } \\
\text { Coefficients }\end{array}$} & \multirow{2}{*}{$\begin{array}{c}\text { Standardized } \\
\text { Coefficients }\end{array}$} & \multirow[t]{2}{*}{$\mathrm{T}$} & \multirow[t]{2}{*}{ Sig. } \\
\hline & & $\mathrm{B}$ & Std. Error & & & \\
\hline & (Constant) & 14,604 & 1,663 & & 8,784 & ,000 \\
\hline 1 & $\begin{array}{l}\text { Budaya } \\
\text { Organisasi }\end{array}$ & ,260 & ,080 & ,283 & 3,256 & ,001 \\
\hline
\end{tabular}

a. Dependent Variable: Motivasi Kerja

Pada tabel 9 terdapat data hasil uji hipotesis, analisis regresi linear sederhana dipakai menguji hipotesis terkait pengaruh dari budaya organisasi terhadap motivasi kerja organisasi Club K. Nilai signifikansi nya adalah 0,001 kurang dari nilai probabilitas signifikan yang bernilai 0,05 maknanya adalah hipotesis awal dapat diterima, dimana variabel $\mathrm{X}$ budaya organisasi berpengaruh terhadap variabel $\mathrm{Y}$ motivasi kerja. Kemudian jika dilihat nilai $t$ adalah 3,256 dan nilai $t$ tabel 1.9796. dari data tersebut maka disimpulkan terdapat pengaruh dari budaya organisasi terhadap motivasi kerja pada organisasi Club K.Hasil dari persamaan regresi linear sederhana yaitu $\mathrm{Y}=14,604+0,260 \mathrm{X}$ yang berarti koefisien regresi pada variabel X menunjukkan angka positif 0,260 dengan konstanta sebesar 14,604.

\section{KESIMPULAN}

Setiap organisasi pastinya memiliki budaya organisasibaik ataupun buruk. Dalam sebuah organisasi budaya yang positif akan membawa pengaruh yang positif juga bagi para anggotanya begitupun sebaliknya. Budaya yang positif juga mampu meningkatkan semangat, motivasi, dan kinerja para anggotanya. Budaya yang baik menimbulkan motivasi yang baik juga dalam bekerja. Dalam analisis regresi linear sederhana diperoleh nilai signifikansi 0,001 dan kurang dari 0,05 dengan hasil persamaan regresinya adalah $\mathrm{Y}=14,604+0,260 \mathrm{X}$. Dari semua hasil uji dan analisis yang dilakukan diperoleh jawaban dari masalah dan tujuan penelitian ini, bahwa budaya organisasi berpengaruh terhadap motivasi kerja anggota organisasi Club K di Fakultas Ilmu Sosial Universitas Negeri Jakarta

\section{SARAN}

Berdasarkan kesimpulan hasil penelitian mengenai pengaruh budaya organisasi terhadap motivasi kerja anggota Club K Universitas Negeri Jakarta peneliti mengajukan saran yang bisa dijadikan solusi dari permasalahan dan pertimbangan dalam mengambil keputusan yaitu :

1. Dalam penelitian ini, diajukan saran supaya penelitian dikemudian hari dilakukan dengan variable lain seperti kinerja, kepemimpinan, motivasi kerja dan faktor lain supaya mendapatkan hasil akurat mengenai pengaruh variable lain pada Organisasi Club K Universitas Negeri Jakarta

2. Membahas mengenai keberanian para anggota yang sudah cukup berani menyampaikan pendapat, peneliti ingin memberikan saran untuk kedepannya bagi ketua organisasi bisa menerapkan sikap kekeluargan dan merangkul anggota diharapkan bagi anggota yang belum bisa menyampaikan pendapat di kemudian hari berani berpendapat di muka umum. 


\section{DAFTAR PUSTAKA}

[1] Ardian, M. (2013). Sikap Masyarakat Surabaya Terhadap Program Acara "'Pesbukers"” Antv. EKomunikasi, 1(1), 11. File:///C:/Users/User/Downloads/Ardian (2013).Pdf

[2] Az Zuhri, F. M., \& Permanasari, K. I. P. (2019). Analisis Budaya Organisasi Terhadap Motivasi Kerja Dalam Meningkatkan Kinerja Karyawan Fis Universitas Negeri Malang. Ekonomi Bisnis, 24(2), 93. Https://Doi.Org/10.17977/Um042v24i2p93-103

[3] Bodroastuti, T. R. I. (2018). Dan Motivasi Kerja Terhadap Kepuasan Kerja Dan Kinerja Karyawan. 20(2), 129-140.

[4] Indriyani, Surya Candra Tjoeng Dan Ratih. (2014). Pengaruh Perceived Organizational Support Terhadap Corporate Entrepreneurship Pada Perusahaan Keluarga Di Jawa Timur. Jurnal Manajemen Bisnis, 2(1).

[5] Masykur, Ruhban; Septuri; Setiawan, Y. (2019). Pengaruh Budaya Organisasi Terhadap Motivasi Kerja Guru Di Sekolah Dasar Ar-Raudah Bandar Lampung. Al-Idarah: Jurnal Kependidikan Islam, 9(Juni 2019).

[6] Ramadhani, S. S., Ahman, E., \& Senen, S. H. (2017). Pengaruh Budaya Organisasi Terhadap Motivasi Dan Kepuasan Kerja Serta Dampaknya Kepada Kinerja Pegawai Direktorat Jendral Pajak. Jurnal Ilmu Manajemen Dan Bisnis, 8(1), 31. Https://Doi.Org/10.17509/Jimb.V8i1.12659

[7] Ridha, M. (2020). Teori Motivasi Mcclelland Dan Implikasinya Dalam Pembelajaran Pai. Palapa, 8(1), 1-16. Https://Doi.Org/10.36088/Palapa.V8i1.673

[8] Sitorus, R. M. T. (2020). Pengaruh Komunikasi Antarpribadi Pimpinan Terhadap Motivasi Ker (I. Selviani (Ed.)). Scopindo Media Pustaka.

[9] Sugiyono. (2019). Metode Penelitian Kuantitatif, Kualitatif Dan R\&D - Mpkk (2 Ed.). Alfabeta.

[10] Sutoro, S. (2020). Pengaruh Budaya Organisasi Terhadap Motivasi Kerja Pegawai Bpsdm Provinsi Jambi. Jurnal Ilmiah Universitas Batanghari Jambi, 20(1), 104. Https://Doi.Org/10.33087/Jiubj.V20i1.863

[11]Tania, N. (2013). Pengaruh Budaya Organisasi Terhadap Motivasi Kerja Karyawan "Studi Kasus Di Pondok Pesantren Moderen Islam Assalam Kota Surakarta.” Skripsi, 1-15.

[12] Taruh, F. (2020). Motivasi Kerja (Meniti Suara Hati Menolak Perilaku Korupsi). Deepublish.

[13] Theresia, L., Lahuddin, A. H., Ranti, G., \& Bangun, R. (2018). The Influence Of Culture, Job Satisfaction And Motivation On The Performance Lecturer/Employees. Proceedings Of The International Conference On Industrial Engineering And Operations Management, 2018-March, 1841-1841. 
[14] Timothy A. Judge \& Robbins, S. P. (2015). Organizational Behavior (16 Ed.). Pearson Education Inc.

[15] Weerasinghe, G. (2017). Organization Culture Impacts On Employee Motivation: A Case Study On An Apparel Company In Sri Lanka. International Journal Of Multidisciplinary Research And Development, 4(4), 59-62.

[16] Yusuf, M. H. (2017). Pengembangan Budaya Organisasi Dalam Lembaga Pendidikan. Tarbawi : Jurnal Pendidikan Islam, 14(1), 81-96. 